\title{
25
}

\section{Marine Ecosystems and Fisheries: Trends and Prospects}

\author{
Manuel Barange, Jose A. Fernandes, Susan Kay, \\ Mostafa A. R. Hossain, Munir Ahmed, \\ and Valentina Lauria
}

\subsection{Introduction}

Bangladesh is a country deeply connected to water, dominated by extensive flood plains, a complex network of rivers, and a dynamic system of estuaries and islands, and a major coastal sea. A significant dependence on aquatic resources also results in growing pressures on coastal ecosystems and added risks from environmental change: the population of Bangladesh

M. Barange ( $\bowtie)$

Food and Agriculture Organization of the United Nations, Rome, Italy

Plymouth Marine Laboratory, Plymouth, UK

J. A. Fernandes $\bullet S$. Kay $\bullet$ V. Lauria

Plymouth Marine Laboratory, Plymouth, UK

M. A. R. Hossain

Department of Fisheries Biology and Genetics, Bangladesh Agricultural

University, Mymensingh, Bangladesh

M. Ahmed

TARA, Dhaka, Bangladesh

(C) The Author(s) 2018

R. J. Nicholls et al. (eds.), Ecosystem Services for Well-Being in Deltas,

https://doi.org/10.1007/978-3-319-71093-8_25 
in its coastal region has doubled since the 1980s. The dependence is further challenged by significant environmental variability, often experienced as a set of cyclones, floods and other hazards.

The dependence on aquatic ecosystems extends to its resources, such as fish and fisheries, which contribute significantly to Bangladeshi culture, economy and tradition. Fisheries supplies more than 60 per cent of the country's protein intake (DoF 2013) at an average per capita consumption of approximately $20 \mathrm{~kg} /$ year (DANIDA-DFID 2003). The sector contributes approximately four and a half per cent to the national gross domestic product (GDP), and provides direct employment to two million people on a full-time basis (DoF 2002) and indirect employment to a further 13 million people (Alam et al. 2012; World Bank 2015). Such is its fisheries dependence that Bangladesh is both the fourth largest inland capture producer in the world (2003-2012) and the sixth largest aquaculture producer (FAO 2016). Since independence in 1971 the fisheries industry has seen steady growth with production tripling in the last two decades (Alam et al. 2012). Between 1984 and 2009 annual average growth in fish production was more than five per cent largely driven by the expansion in inland aquaculture fisheries, which grew at a rate of almost ten per cent per year (Golub and Varma 2014).

This chapter explores how climate change will affect marine fisheries in Bangladesh, and how management interventions can minimise or exacerbate such impacts. It will demonstrate that the marine ecosystem of Bangladesh will remain productive but that the species benefiting from this production may change. This is illustrated by investigation of the specific impacts of climate change on Hilsa shad (Tenualosa ilisha) and Bombay duck (Harpadon nehereus), two of the fish that contribute the most to food security and nutrition in Bangladesh.

\subsection{Structure of Fisheries Sector}

The fishery of Bangladesh includes marine, inland and aquaculture sectors (Fig. 25.1), each one with its own specific stressors and production trends. In 2012-2013 the full fisheries sector produced 3.4 million tonnes of fish. Marine and inland fisheries are connected because both target in particular 


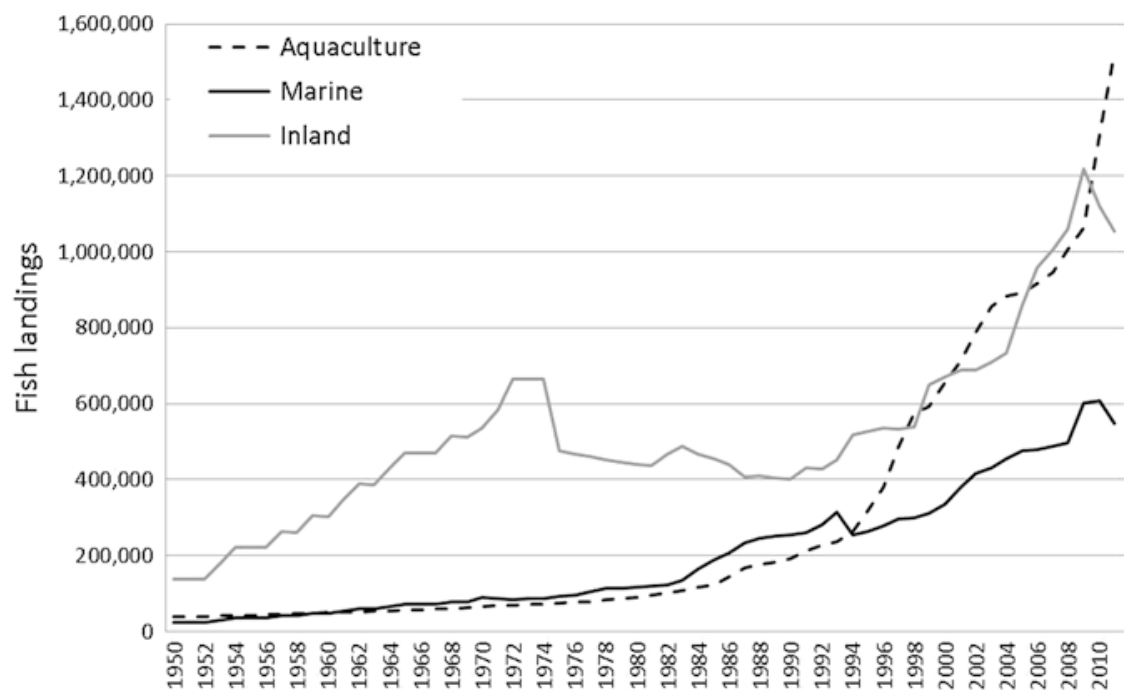

Fig. 25.1 Fisheries production (expressed in tonnes) in Bangladesh 1950-2012: marine catches, inland catches and aquaculture production (Based on data from the FAO Global database)

Hilsa shad, a fish that spends part of its life cycle in the sea and part of it in rivers. Aquaculture activities are also connected with capture fisheries because they depend on the provision of larvae and juveniles from rivers and marine ecosystems (Kathun 2004). However, there are many processes involved in the development of aquaculture as an industrial activity, beyond the availability of natural fish and shellfish resources. Fisheries has been continuously growing in Bangladesh since 1950 (Fig. 25.1), with aquaculture providing the majority of production in recent years.

The marine-based fishery in particular, which relies entirely on natural production processes, is subdivided into subsistence, artisanal and industrial. The artisanal sector is the most productive with circa 500,000 tonnes of fish landings in 2012 (94 per cent of volume of landings). Subsistence fisheries are of greatest importance for national food provision, and focuses on catches of species of lower commercial value. The only industrial fishing developed in Bangladesh operates out of Chittagong on the east coast and comprises two distinct industrial fisheries: shrimp trawl and bottom trawl (FAO 2006). 


\subsection{Marine Fish Catches and Their Management}

Freshwater habitats in Bangladesh are inhabited by 260 fin fish species, 25 species of prawn and 25 species of turtles (Ali 1999), as well as 23 exotic fin fish species that were introduced for aquaculture purposes (Hossain 2010). Marine waters are habitat to 475 species of fin fish, of which 65 are of economic importance, and host 38 species of marine shrimps (Ali 1999).

Hilsa shad is the biggest fishery and the national fish of Bangladesh. Locally known as ilish or ilisha, it is a euryhaline anadromous fish found in marine, coastal and freshwater environments. A significant part of its catch is exported to India, where it is especially consumed in religious holidays and by Bangladeshis living in a number of outside countries. In 2012-2013, Hilsa contributed singlehandedly about ten per cent of the total fish production of Bangladesh, with a market value of US\$2250 million, about one per cent of Bangladesh's GDP. In the last two decades, Hilsa production from inland waters has declined by about 20 per cent, whereas marine water yield has increased threefold (Kathun 2004).

Bombay duck supplies the second largest fish catch in the Bangladesh coastal region and is the most popular subsistence fishery, representing over 12 per cent of the catch (1.7 million tonnes), and consumed fresh or dried. In addition to its food provision role, it is a lucrative fishery in the Bay of Bengal despite its price being six times lower than Hilsa (65 BDT. kg-1 versus 430 BDT.kg-1; 1US\$=79 Bangladesh Taka (BDT)).

Bangladesh has a centralised fisheries management system under the Department of Fisheries of the Ministry of Livestock and Fisheries. The present Fisheries Policy was adopted in 1998 to enhance resources and production, reduce poverty through self-employment in the sector, supply the need for animal protein, achieve economic growth and earn foreign exchange while maintaining ecological balance, biodiversity and public health. In 2006, the Ministry of Fisheries and Livestock adopted a Fisheries Strategy pushing further towards poverty reduction, co-management and conservation of resources. But even though the Hilsa fishery is regulated through some technical management measures, such as reduction in mesh size and fishing closures, the overall management of fishery resources in 
the country is currently insufficient to control effort. This is primarily due to the lack of funding and resources committed to sustainable fisheries management (FAO 2003).

\subsection{Estimating the Effects of Climate Change on the Marine Ecosystems and Fisheries of Bangladesh}

In fish-dependent economies such as Bangladesh (Toufique and Belton 2014), the combination of climate change, population growth and protein consumption patterns is a significant amplifier of pressures on critical national resources (Delgado et al. 2003; Merino et al. 2012). Yet there are no major studies that have projected the structure and availability of aquatic resources and ecosystem services into the future accounting for the impacts of climate change. This research analyses the prospects for fisheries maintaining its critical role in providing employment and provisioning ecosystem services and nutrition across the delta region.

Previous analyses have predicted a decrease in the productive potential of fisheries in South and Southeast Asia as a result of climate change (Barange et al. 2014). Understanding how this impact translates into the future provision of fish products is crucial for the sustainability of fisheries-dependent communities in coming decades (see Chap. 23). In previous work based on simpler models, Merino et al. (2012) concluded that marine fisheries production in Bangladesh may be reduced by five per cent by 2050 , leaving aquaculture to produce between 0.3 and 3.8 million tonnes of fish to achieve national fish consumption targets of between 13 and $31 \mathrm{~kg}$ fish/capita, accounting for expected human population growth. In order to better quantify how climate change will change the marine fish production potential in Bangladesh, a combination of atmospheric, hydrological, ocean circulation and ocean biogeochemical models is used (Fig. 25.2). A full description of these models is detailed in Fernandes et al. (2016): here, a summary of these models is provided.

Climate data were taken from the UK Met Office regional climate model (RCM) HadRM3P, which is dynamically downscaled from the 

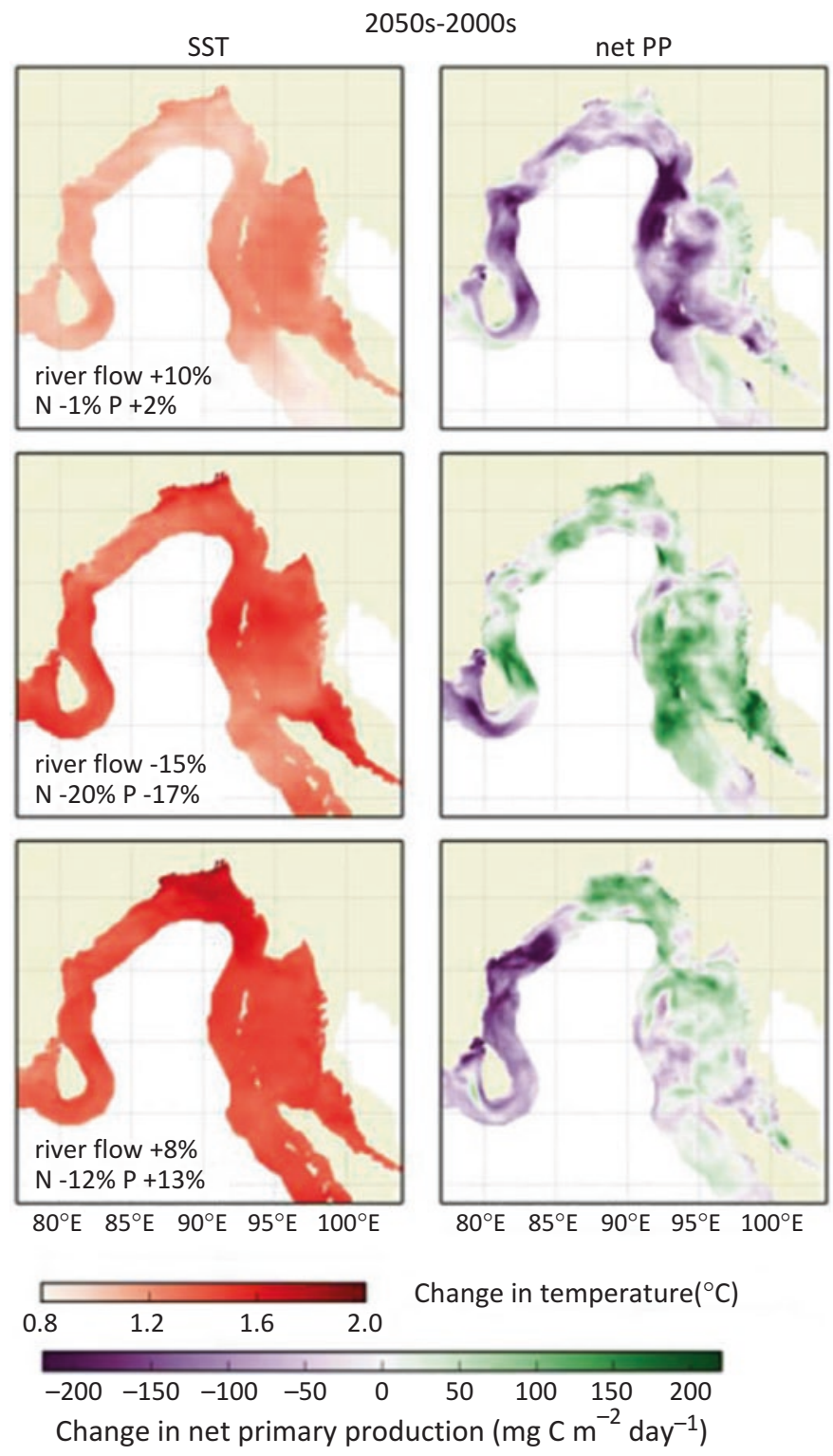

Fig. 25.2 Changes in sea surface temperature (SST) and net primary production (net PP) projected for the Bay of Bengal by 2050s, compared to baseline of values for the 2000s. The rows show results for the three climate ensemble runs Q0 (top row), Q8 (middle) and Q6 (bottom row). Changes in river flow volume, nitrate (N) and phosphate (P) loads of the GBM rivers are shown in the left-hand panel of each pair (Reproduced with permission from Fernandes et al. 2016 - Published by Oxford University Press) 
global circulation model HadCM3 (see Chap. 11 and Caesar et al. 2015). As delta regions are particularly sensitive to precipitation and river runoff, outputs from an integrated catchment model (see Chap. 13 and Whitehead et al. 2015a, b) were used to determine run-off and associated nutrient loadings from the delta rivers into the Bay of Bengal. The model took account of both climatic scenarios (Q0, Q8, Q16) and patterns of upstream water use according to three socio-economic scenarios (Less Sustainable (LS), Business As Usual, (BAU), More Sustainable (MS)) scenarios (Whitehead et al. 2015a, b). The results of the Q0-BAU, Q8-LS and Q16-MS were used in further simulations.

A regional POLCOMS-ERSEM coupled model (Holt et al. 2009; Butenschön et al. 2016) was used to project both the physical state of the ocean (temperature, salinity, currents, light level), as well as the biogeochemistry and plankton production in the Bay of Bengal (see Chap. 14). The model simulates the dynamics of nutrients (C, P, N and Si), phytoplankton, zooplankton and bacteria, as well as particulate and dissolved organic matter. The model domain covers the entire coastal area of Bangladesh up to $200 \mathrm{~km}$ beyond the edge of the continental shelf, with a horizontal resolution of $0.1^{\circ}$ and 42 vertical levels. For each climate dataset, the model was run continuously for 1971-2099.

Outputs from the POLCOMS-ERSEM model were then used to drive a dynamic marine ecosystem model that predicts potential production by size class of fish, taking into account food availability, predation effects and temperature effects on feeding and mortality (Blanchard et al. 2012). Size-based methods like this are useful in that they capture the basic metabolic properties and dynamics of marine food webs, describing energy flux and production by size class, independent of species' ecology (Blanchard et al. 2012). To make specific projections for key species, however, a second model, called SS-DBEM, was used (Fernandes et al. 2013, 2016, 2017), which projects changes in species distribution and abundance over time while explicitly considering changes in production, dispersal and physiology as a result of changing ocean conditions, as well as species interactions (Fernandes et al. 2013). The size-spectrum model was applied to explore potential changes in the total productivity of the Bangladesh Exclusive Economic Zone under both climate change and 
fishing scenarios and the SS-DBEM for the two target species (Hilsa shad and Bombay duck), for up to 2099.

In order to estimate potential fish catches not only need to project production potential is required but also management interventions. Fisheries management in Bangladesh is limited to technical measures that are insufficient to control and limit overfishing practices. In order to understand the importance of management interventions, three plausible fisheries management scenarios were defined, based on specific levels of fishing pressure in relation to the species' maximum sustainable yield (MSY). MSY is defined as the highest average theoretical equilibrium catch that can be continuously taken from a stock under average environmental conditions (Hilborn and Walters 1992). It aims to maintain the population size at the point of maximum growth rate by harvesting the individuals that would normally be added to the population, allowing the population to continue to be productive indefinitely. The three scenarios are based on adjusting fishing mortality, the parameter that determines the amount of fish that is removed from the stock through fishing. These scenarios are named 'Sustainability', 'Business As Usual', and 'OverFishing'. The sustainability scenario (MSY) involves adjusting the fishing mortality $\left(\mathrm{F}_{\mathrm{MSY}}\right)$ to ensure the population remains at levels of biomass consistent with their maximum Sustainable Yield. This is a theoretical value that results in maximum catches while maintaining the population at their productivity peak. The Business As Usual scenario (BAU) represents fishing mortality that is consistent with the average estimates of fishing mortality in the country $\left(\mathrm{F}_{\mathrm{BAU}}\right)$, which as illustrated later are below long-term sustainability. The average fishing mortality for Hilsa shad in recent years, the largest fishery in the country, is 1.86 , or three times the fishing mortality consistent with MSY $\left(\mathrm{F}_{\mathrm{MSY}}\right)$. Hilsa shad and many of the brackish species in the Bay of Bengal are considered to be being exploited at that rate for the purpose of the BAU scenario. The OverFishing scenario $\left(\mathrm{F}_{\mathrm{OF}}\right)$, on the other hand, involves the highest level of exploitation and corresponds to a scenario where management is not a constraint to the fishery. Initial runs indicate collapse of catches and biomass at $4^{*} \mathrm{MSY}\left(\mathrm{F}_{\mathrm{m}}\right.$ of 2.4). The three scenarios are therefore consistent with status quo (BAU), inaction (OF) and active management (MSY). 


\subsection{Climate Change Impacts on the Bay of Bengal Ecosystem}

Projections of change by the middle of the twenty-first century show a steady rise in sea surface temperature throughout the Bay of Bengal but a more mixed picture for river flows, nutrients and net primary production (Fig. 25.2). The temperature rise is greatest for the Q16 climate run, which has the highest climate sensitivity. River flows vary between increases of ten per cent to decreases of 15 per cent, depending on the climate projection. Similar variability is observed in the nutrient loading. There is a consistent fall in net primary production across most of the northern Bay of Bengal under Q0. Primary production in the Exclusive Economic Zone (EEZ) of Bangladesh rises in both of the warmer runs, Q8 and Q16, and is greatest for Q8. The EEZ is the zone prescribed by the UN Convention on the Law of the Sea over which a state has special rights regarding the exploration and use of marine resources.

Figure 25.3 shows how these changes in environmental conditions and primary production affect the overall fish production potential of the Bangladeshi EEZ. The results indicate that all three climate runs result in declines in fish productivity. Averaging the results per decade shows that

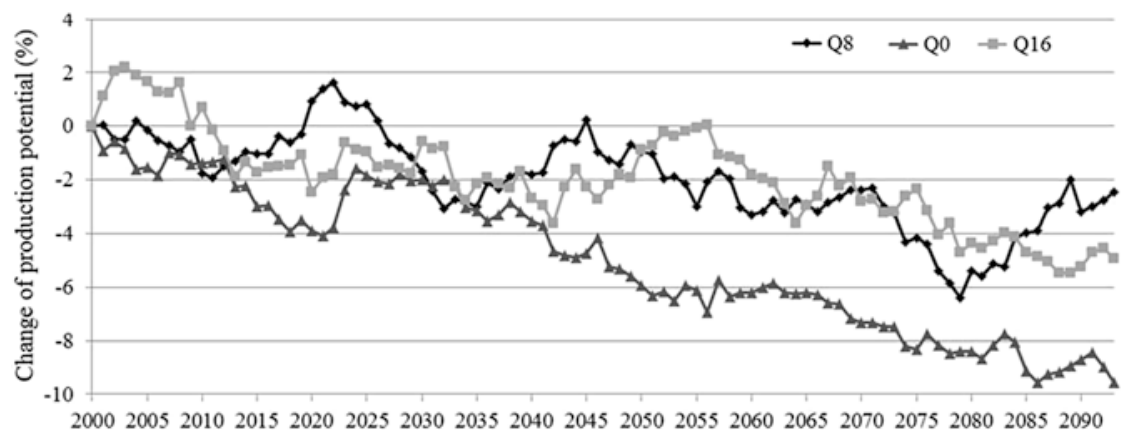

Fig. 25.3 Time series of changes in projected total fisheries production potential in the Bangladesh EEZ according to the three climate ensemble runs (Q0, Q8 and Q16) and in the absence of fisheries extractions. Values are expressed as a percentage deviation from the 2000 production for each ensemble run (Reproduced with permission from Fernandes et al. 2016 - Published by Oxford University Press) 
the total fish productivity would decline between 1.3 per cent and 4.9 per cent by 2050 , and between 2.6 per cent and 8.3 per cent by 2100 , depending on the climatic ensemble run considered. These are not very significant changes in potential production, and close to the error margins of such a modelling exercise.

\subsection{The Role of Management Interventions}

In order to explore the impact of particular fisheries, management scenarios model runs using the species-based model for Hilsa shad and Bombay duck were undertaken. For this exercise, averaged outputs of the three climate ensembles were calculated to enable a focus specifically on the relative impacts of fisheries management decisions. The results are presented relative to the year 2000 model outputs (not the actual catches), but the different management interventions are implemented at year 1980, as the model needs to settle and reflect the interventions before the period of analysis. For this reason, by 2000 the three management trajectories already diverge from the actual recorded catches. Results conclude that both Hilsa shad and Bombay duck catches will decline over time regardless of the fisheries management regime, but to different degrees (Fig. 25.4). For Hilsa the decline stabilises under MSY management at 175,000 t by 2035 , while it virtually collapses around the same period under the $\mathrm{OF}$ scenario. A significant inter-annual variability is also observed (Fig. 25.4). By the 2050s the decline in catches is between 39 per cent (under MSY) and 87 per cent. For Bombay duck inter-annual variability is reduced (Fig. 25.4), and while catch potential declines continuously under all management scenarios, they do not lead to biological collapse. By the 2050s this decline is around 35 per cent for all management scenarios. Potential catches are on average higher in the more sustainable scenarios (MSY) than in the BAU scenario for both species (91 per cent in Hilsa Shad and 37 per cent in Bombay duck by the 2050s).

It is useful to compare the outcomes of the BAU scenario in the 2000s decade with those of a more sustainable scenario in coming decades. The results indicate that a change to sustainable management would result in a very minor decline in potential catches by the 2020s but a still significant 

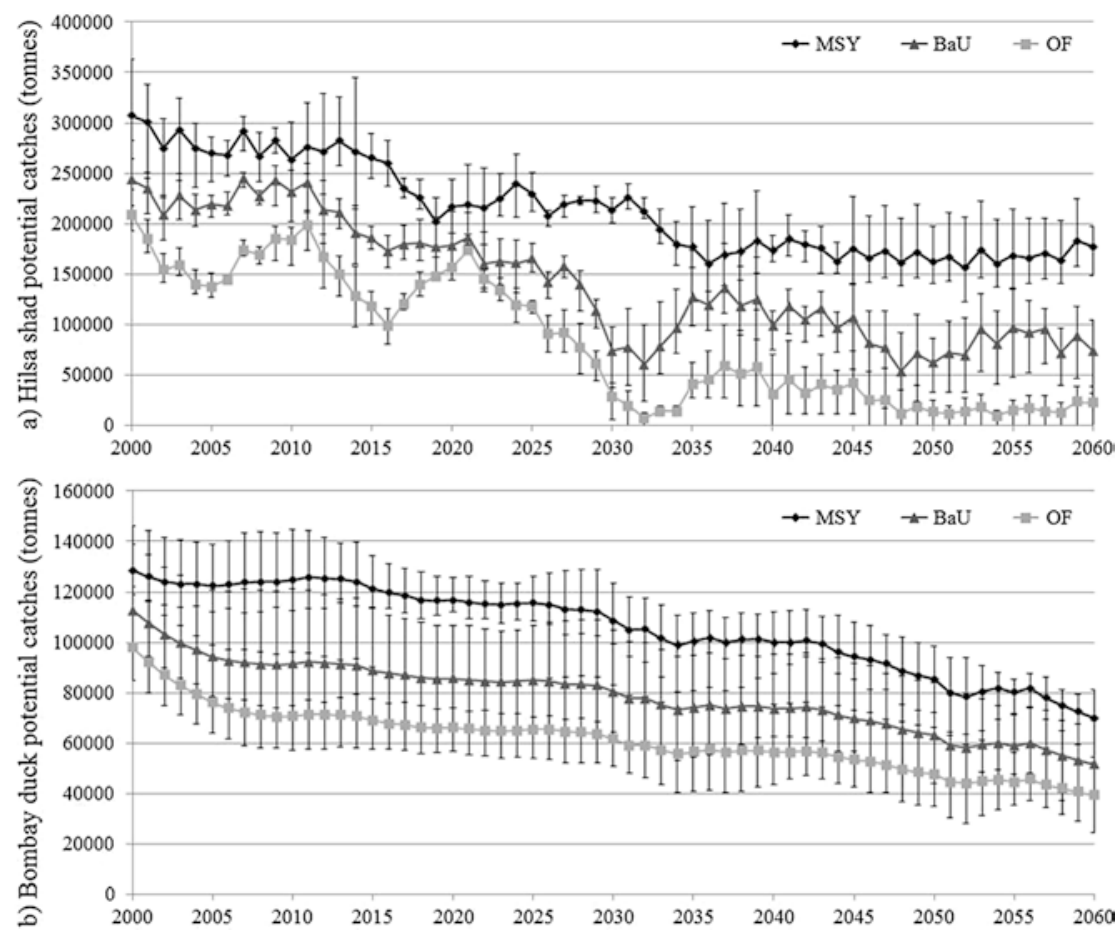

Fig. 25.4 Time series of catch potential projections ( $\mathrm{t}$ ) in the Bangladesh EEZ for Hilsa shad (a) and Bombay duck (b) under different fisheries management scenarios (MSY or Sustainable exploitation, BAU or Business As Usual and OF or OverFishing scenario). Error bars indicate variability between the three climate ensemble runs (Q0, Q8 and Q16) and associated river run-off and nutrient loadings (Reproduced with permission from Fernandes et al. 2016 - Published by Oxford University Press)

(25 per cent) decline by the 2050s (Table 25.1). Conversely, a future that follows BAU with an OF scenario will bring catches by 2050s almost 95 per cent lower than in the BAU scenario for the start of the twenty-first century (Table 25.1). For Bombay duck, potential catches by 2020s under an MSY scenario will produce over 20 per cent more fish than under BAU at the start of the century, with a decline of less than 20 per cent by the end of the projection period (Table 25.1). Conversely, maintaining BAU fishing to the end of century would result in 40 per cent decline in catch potential. What this demonstrates is that management 


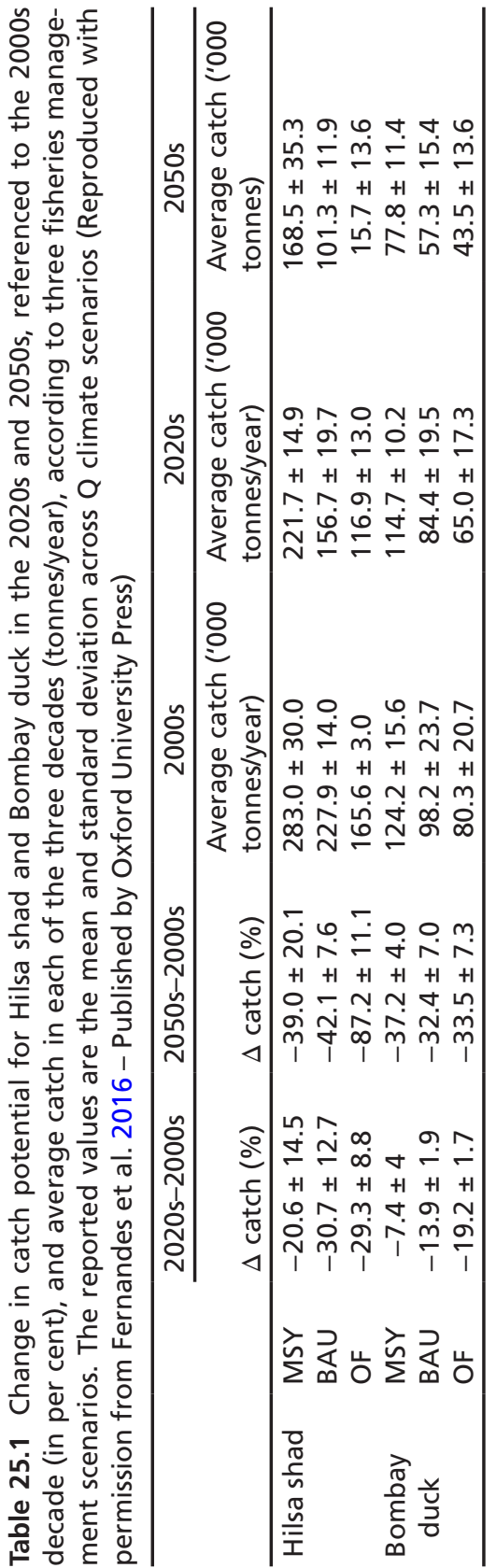


interventions have the capability to mitigate or exacerbate the effects of climate change on ecosystem productivity.

\subsection{Implications and the Prospects for Fisheries}

In spite of the slight increase in primary production in Bangladeshi waters by the mid twenty-first century, projections indicate some decreases in the potential fish production. The complex relationship between temperature and primary production change may result in a higher proportion of fish biomass of smaller size, despite lower total fish biomass. Marine and inland fish catches in Bangladesh have doubled since 1995 reaching 1.6 million tonnes per year (Fig. 25.1), of which Hilsa has contributed ca. 350,000 tonnes. The analysis in this chapter indicates no evidence of increased productivity, and hence it is likely that the reported increase in catches is driven directly by growing demand for fish products rather than increase productivity of the Bangladesh EEZ. Increases in Bangladesh population from 120 million to 158 million people since 1995 (World Bank 2015) and growing protein consumption (from 42.1 in 2005 to 49.5 in 2010, grammes per capita per day, BBS 2011) are putting additional pressure on resources whose productivity is limited. Managing this growth in demand, including better use of not just marine but also inland and aquaculture resources (Bene et al. 2015) would be important as climate change impacts start to make themselves felt.

The analysis here suggests larger decreases are projected for the two main species compared to the total fisheries productivity change: decreases in Hilsa and Bombay duck may provide ecological space for other species to replace the main targets of the fishery. Possible replacement could include Chacunda Gizzard Shad (Anodontostoma chacunda) and Toli Shad (Tenualosa toli) for Hilsa Shad. It is well known that the complexity of ecological interactions in the marine food web makes it difficult to extrapolate studies on individual species to community or ecosystem level (Walther et al. 2002). Thus, it is quite possible to observe differential impacts at the community level compared to species patterns. 
The analysis also demonstrates that the management options to be followed in coming decades are crucial for the sustainability of fisheries and their role as a nutritional and economic resource for the country (see Chaps. 23 and 27). The implementation of sustainable management practices for Hilsa would stabilise the marine catch to approx. 170,000 tonnes by the 2050s, but that continuing with current fishing mortalities would reduce this to around 100,000 tonnes. A decrease in Hilsa shad catch would have important consequences for a species with intrinsic cultural value, and may cause a shift in the workforce from fishing to other livelihood options (Hossain et al. 2015; Nicholls et al. 2015).

Bombay duck productivity is around half that of Hilsa shad, but the catches and biomass are more stable. The projections here indicate that catches of Bombay duck may not collapse as a result of unsustainable fishing practices and climate effects by 2060, contrary to projections for Hilsa. The reason for the different response compared to Hilsa relies on its different sensitivity to environmental and climate conditions and a broader range of feeding options (Fernandes et al. 2016; Zhang and Jin 2014).

The impact that changes in the extension and composition of mangroves would have on fish production are not included in the model. Although the importance of mangroves as fish habitats and nursery grounds is well recognised (Islam and Haque 2004; Hutchison et al. 2014), the exact impacts of changes on fish populations are still uncertain and unquantified.

Although this chapter focuses explicitly on marine environments and their resources, climate change impacts do include coastal zones and their associated inland fisheries. Drought coupled with siltation and lowering water level is reducing overwintering habitat for indigenous fish species, resulting in reduced fish recruitment. Lower dry season flows in major rivers have and will continue to deplete riverine fisheries. Due to a decrease in groundwater and surface water, extreme pressure has been exerted on floodplains to convert them to crop fields, brick kiln and other infrastructures, resulting in worrying declines in fish diversity and production. Erratic and irregular rainfall as well as temperature change will affect the readiness, maturity and gonad development of fishes in the breeding season. Higher water temperature brings changes in physiology 
and sex ratios of fish species, altered timing of spawning, migrations, and peak abundance, changes in timing and levels of productivity across marine and freshwater systems and increased invasive species, diseases and algal blooms. Thus, the effects quantified here are not comprehensive for other inland fisheries.

Since fishing is the second most important source of livelihood in coastal Bangladesh, exploring plausible future trajectories of the resources will allow the exploration of alternatives futures comparing the use of all natural ecosystem services of Bangladesh as a tool to aid sustainable resource management and regional development planning.

\subsection{Conclusions}

Results show that the impacts of climate change, under greenhouse emissions scenario A1B, are likely to decrease the potential total fish production in the Bangladesh EEZ by less than ten per cent. However, these impacts are larger for the two major species (Hilsa shad and Bombay duck), even under sustainable management practices.

It is demonstrated that sustainable management practices would stabilise the marine catch of Hilsa around 170,000 tonnes by the 2050s decade, approximately 70 per cent of current catches. However, failure to implement sustainable management practices, combined with climate effects could reduce Hilsa catches by 2050 by up to 90 per cent of current catches. On the other hand, catches of Bombay duck may not collapse as a result of unsustainable fishing practices and climate effects by 2060 . Sustainable management measures would maintain current catches to a large extent. The reasons for the different response rely on the fact that Hilsa has slightly higher estimated intrinsic population growth rates and adult movement rate compared to Bombay duck, allowing it to track environmental changes more closely.

Hilsa shad is the largest fishery by volume in Bangladesh and a species with very significant economic and cultural value. Bombay duck is the second highest catch in Bangladesh and is a much cheaper fish than Hilsa Shad. The analyses indicate that environmental and climate change would impact negatively Bangladesh fisheries. However, it is demonstrated 
that good management can mitigate catches losses, while bad or no management can exacerbate the impacts of climate change.

The results of this research should allow for the exploration of future sustainable trajectories of the fishery sector through testing plausible scenarios. These could be used as a tool to aid sustainable resource management and regional development planning.

Fish is critically important to food security and good nutrition (Beveridge et al. 2013), and fisheries a crucial provisioning ecosystem service in Bangladesh. Fisheries not only provide food but also livelihoods and economic trade, particularly important for coastal communities who are often among the poorest in society. Ensuring the sustainability of the underlying marine and inland resources, in the face of climate change is crucial (see Chap. 2). This research has demonstrated that this ecosystem service can be maximised through responsive and effective management, for the purpose of feeding and supporting coastal communities. Inaction has a cost, and in the context of climate change, this cost would be too high in terms of food provision alone to be forgotten.

\section{References}

Alam, M.F., M.S. Palash, M.I.A. Mian, and M.M. Dey. 2012. Marketing of major fish species in Bangladesh: A value chain analysis. 'A value-chain analysis of international fish trade and food security with an impact assessment of the small-scale Sector' - Project report. Rome: Food and Agriculture Organization of the United Nations.

Ali, M.Y. 1999. Fish resources vulnerability and adaptation to climate change in Bangladesh. In Vulnerability and adaptation to climate change for Bangladesh, ed. S. Huq, Z. Karim, M. Asaduzzaman, and F. Mahtab, 113-124. Dordrecht: Springer Netherlands.

Barange, M., G. Merino, J.L. Blanchard, J. Scholtens, J. Harle, E.H. Allison, J.I. Allen, J. Holt, and S. Jennings. 2014. Impacts of climate change on marine ecosystem production in societies dependent on fisheries. Nature Climate Change 4 (3): 211-216. https://doi.org/10.1038/nclimate2119.

BBS. 2011. Foreign trade statistics of Bangladesh, 2010-2011. Dhaka: Bangladesh Bureau of Statistics (BBS). 
Bene, C., M. Barange, R. Subasinghe, P. Pinstrup-Andersen, G. Merino, G.-I. Hemre, and M. Williams. 2015. Feeding 9 billion by 2050-putting fish back on the menu. Food Security 7 (2): 261-274. https://doi.org/10.1007/ s12571-015-0427-z.

Beveridge, M.C.M., S.H. Thilsted, M.J. Phillips, M. Metian, M. Troell, and S.J. Hall. 2013. Meeting the food and nutrition needs of the poor: The role of fish and the opportunities and challenges emerging from the rise of aquaculturea. Journal of Fish Biology 83 (4): 1067-1084. https://doi.org/10.1111/ jfb.12187.

Blanchard, J.L., S. Jennings, R. Holmes, J. Harle, G. Merino, J.I. Allen, J. Holt, N.K. Dulvy, and M. Barange. 2012. Potential consequences of climate change for primary production and fish production in large marine ecosystems. Philosophical Transactions of the Royal Society B-Biological Sciences 367 (1605): 2979-2989. https://doi.org/10.1098/rstb.2012.0231.

Butenschön, M., J. Clark, J.N. Aldridge, J.I. Allen, Y. Artioli, J. Blackford, J. Bruggeman, P. Cazenave, S. Ciavatta, S. Kay, G. Lessin, S. van Leeuwen, J. van der Molen, L. de Mora, L. Polimene, S. Sailley, N. Stephens, and R. Torres. 2016. ERSEM 15.06: A generic model for marine biogeochemistry and the ecosystem dynamics of the lower trophic levels. Geoscientific Model Development 9 (4): 1293-1339. https://doi.org/10.5194/gmd-9-1293-2016.

Caesar, J., T. Janes, A. Lindsay, and B. Bhaskaran. 2015. Temperature and precipitation projections over Bangladesh and the upstream Ganges, Brahmaputra and Meghna systems. Environmental Science-Processes and Impacts 17 (6): 1047-1056. https://doi.org/10.1039/c4em00650j.

DANIDA-DFID. 2003. The future for fisheries. Findings and recommendations from the fisheries sector review and future development Study, FAO Representation - Bangladesh, 65p. Available from http://www.lcgbangladesh.org/

Delgado, C.L., N. Wada, M.W. Rosegrant, S. Meijer, and M. Ahmed. 2003. Fish to 2020: Supply and demand in changing global markets. Worldfish Center Technical Report 62. Washington, DC/Penang: International Food Policy Research Institute.

DoF. 2002. Fisheries resources survey system (2001-2002). Dhaka: Department of Fisheries (DOF), Government of the People's Republic of Bangladesh. . 2013. National fish week 2013 compendium (in Bengali). Dhaka: Department of Fisheries (DOF), Government ofthe People's Republic of Bangladesh. 
FAO. 2003. Subregional review: Eastern Indian Ocean. Review of the state of world marine capture fisheries management: Indian Ocean. FAO Fisheries Technical Paper. No. 488. Rome: Food and Agriculture Organization of the United Nations (FAO). http://www.fao.org/docrep/009/a0477e/a0477e05. htm. Accessed 12 Aug 2015.

2006. Review of the state of world marine capture fisheries management: Indian Ocean. Rome: Fishery and Aquaculture Economics and Policy Division, Food and Agricultural Organization of the United Nations (FAO). - 2016. The state of the world fisheries and aquaculture - 2016. Contributing to food security and nutrition for all. Rome: Food and Agricultural Organization of the United Nations (FAO).

Fernandes, J.A., W.W.L. Cheung, S. Jennings, M. Butenschoen, L. de Mora, T.L. Froelicher, M. Barange, and A. Grant. 2013. Modelling the effects of climate change on the distribution and production of marine fishes: Accounting for trophic interactions in a dynamic bioclimate envelope model. Global Change Biology 19 (8): 2596-2607. https://doi.org/10.1111/gcb.12231.

Fernandes, J.A., S. Kay, M.A.R. Hossain, M. Ahmed, W.W.L. Cheung, A.N. Lázár, and M. Barange. 2016. Projecting marine fish production and catch potential in Bangladesh in the 21st century under long-term environmental change and management scenarios. ICES Journal of Marine Science 73 (5): 1357-1369. https://doi.org/10.1093/icesjms/fsv217.

Fernandes, J.A., E. Papathanasopoulou, C. Hattam, A.M. Queirós, W.W.W.L. Cheung, A. Yool, Y. Artioli, E.C. Pope, K.J. Flynn, G. Merino, P. Calosi, N. Beaumont, M.C. Austen, S. Widdicombe, and M. Barange. 2017. Estimating the ecological, economic and social impacts of ocean acidification and warming on UK fisheries. Fish and Fisheries 18 (3): 389-411. https://doi.org/10.1111/faf.12183.

Golub, S., and A. Varma. 2014. Fishing exports and economic development of least developed countries: Bangladesh, Cambodia, Comoros, Sierra Leone and Uganda. Paper prepared for United Nations Conference on Trade and Development (UNCTAD). Swarthmore: Swarthmore College. http://www.swarthmore. edu/profile/stephen-golub. Accessed 4 May 2016.

Hilborn, R., and C.J. Walters. 1992. Quantitative fisheries stock assessment: Choice, dynamics and uncertainty. New York: Chapman \& Hall.

Holt, J., J. Harle, R. Proctor, S. Michel, M. Ashworth, C. Batstone, I. Allen, R. Holmes, T. Smyth, K. Haines, D. Bretherton, and G. Smith. 2009. Modelling the global coastal ocean. Philosophical Transactions of the Royal Society a-Mathematical Physical and Engineering Sciences 367 (1890): 939-951. https://doi.org/10.1098/rsta.2008.0210. 
Hossain, M.A.R. 2010. Inland fisheries resource enhancement and conservation in Bangladesh. In Inland fisheries enhancement and conservation in Asia (RAP Publication 2010/22), ed. M. Weimin, S. De Silva, and B. Davy, 1-17. Bangkok: Regional Office for the Asia and the Pacific, Food and Agriculture Organisation (FAO).

Hossain, M.S., L. Hein, F.I. Rip, and J.A. Dearing. 2015. Integrating ecosystem services and climate change responses in coastal wetlands development plans for Bangladesh. Mitigation and Adaptation Strategies for Global Change 20 (2): 241-261. https://doi.org/10.1007/s11027-013-9489-4.

Hutchison, J., M. Spalding, and P. zu Ermgassen. 2014. The role of mangroves in fisheries enhancement. Arlington/Wageningen: The Nature Conservancy and Wetlands International.

Islam, M.S., and M. Haque. 2004. The mangrove-based coastal and nearshore fisheries of Bangladesh: Ecology, exploitation and management. Reviews in Fish Biology and Fisheries 14 (2): 153-180. https://doi.org/10.1007/ s11160-004-3769-8.

Kathun, F. 2004. Fish trade liberalization in Bangladesh: Implications of SPS measures and eco-labelling for the export-oriented shrimp sector. Policy Research Implications of liberalization of fish trade for developing countries. Project PR26109. Rome: United Nations Food and Agriculture organisation (FAO). Merino, G., M. Barange, J.L. Blanchard, J. Harle, R. Holmes, I. Allen, E.H. Allison, M.C. Badjeck, N.K. Dulvy, J. Holt, S. Jennings, C. Mullon, and L.D. Rodwell. 2012. Can marine fisheries and aquaculture meet fish demand from a growing human population in a changing climate? Global Environmental Change 22 (4): 795-806. https://doi.org/10.1016/j. gloenvcha.2012.03.003.

Nicholls, R.J., P. Whitehead, J. Wolf, M. Rahman, and M. Salehin. 2015. The Ganges-Brahmaputra-Meghna delta system: Biophysical models to support analysis of ecosystem services and poverty alleviation. Environmental ScienceProcesses and Impacts 17 (6): 1016-1017. https://doi.org/10.1039/c5em90022k. Toufique, K.A., and B. Belton. 2014. Is aquaculture pro-poor? Empirical evidence of impacts on fish consumption in Bangladesh. World Development 64: 609-620. https://doi.org/10.1016/j.worlddev.2014.06.035.

Walther, G.-R., E. Post, P. Convey, A. Menzel, C. Parmesan, T.J.C. Beebee, J.-M. Fromentin, O. Hoegh-Guldberg, and F. Bairlein. 2002. Ecological responses to recent climate change. Nature 416 (6879): 389-395. Licence https://doi.org/10.1038/416389a.

Whitehead, P.G., E. Barbour, M.N. Futter, S. Sarkar, H. Rodda, J. Caesar, D. Butterfield, L. Jin, R. Sinha, R. Nicholls, and M. Salehin. 2015a. Impacts 
of climate change and socio-economic scenarios on flow and water quality of the Ganges, Brahmaputra and Meghna (GBM) river systems: Low flow and flood statistics. Environmental Science-Processes and Impacts 17 (6): 1057-1069. https://doi.org/10.1039/c4em00619d.

Whitehead, P.G., S. Sarkar, L. Jin, M.N. Futter, J. Caesar, E. Barbour, D. Butterfield, R. Sinha, R. Nicholls, C. Hutton, and H.D. Leckie. 2015b. Dynamic modeling of the Ganga river system: Impacts of future climate and socio-economic change on flows and nitrogen fluxes in India and Bangladesh. Environmental Science-Processes and Impacts 17 (6): 1082-1097. https://doi. org/10.1039/c4em00616j.

World Bank. 2015. Total population for Bangladesh. World Bank Group. http:// data.worldbank.org/indicator/SP.POP.TOTL/countries/BD?display=graph. Accessed 11 Aug 2015.

Zhang, B., and X. Jin. 2014. Feeding habits and ontogenetic diet shifts of Bombay duck, Harpadon nehereus. Chinese Journal of Oceanology and Limnology 32 (3): 542-548. https://doi.org/10.1007/s00343-014-3085-7.

Open Access This chapter is licensed under the terms of the Creative Commons Attribution 4.0 International License (http://creativecommons.org/licenses/ by/4.0/), which permits use, sharing, adaptation, distribution and reproduction in any medium or format, as long as you give appropriate credit to the original author(s) and the source, provide a link to the Creative Commons license and indicate if changes were made.

The images or other third party material in this chapter are included in the chapter's Creative Commons license, unless indicated otherwise in a credit line to the material. If material is not included in the chapter's Creative Commons license and your intended use is not permitted by statutory regulation or exceeds the permitted use, you will need to obtain permission directly from the copyright holder.

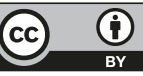

